\title{
An update on microRNAs as potential novel therapeutic targets in testicular germ cell tumors
}

\author{
Marco De Martino ${ }^{1,2}$, Francesco Esposito ${ }^{2}$, Paolo Chieffi ${ }^{1, *}$ \\ ${ }^{1}$ Dipartimento di Psicologia, Università della Campania "Luigi Vanvitelli", Caserta, Italy; \\ ${ }^{2}$ Istituto di Endocrinologia ed Oncologia Sperimentale-CNR c/o Dipartimento di Medicina Molecolare e Biotecnologie Mediche, Università degli \\ Studi di Napoli "Federico II", Napoli, Italy.
}

\begin{abstract}
SUMMARY Testicular germ cell tumors (TGCTs) are the most frequent solid malignant tumors in men 2040 years of age and the most frequent cause of death from solid tumors in this age group. Recent studies have underscored the fact that miRNA deregulation is a feature of carcinogenesis, including TGCT development and progression. MiRNAs are a group of small noncoding RNAs that bind to the 3 '-untranslated region (UTR) of the targeted mRNAs, thus causing mRNA degradation or the inhibition of its translation, regulating gene expression in a temporal and tissue-specific manner. However, few miRNAs have been found to play key roles in TGCTs; recently, other miRNAs have been identified, representing novel potential therapeutic targets.
\end{abstract}

Keywords HMGA1, microRNA, testicular germ cell tumor (TGCT), seminoma

Among solid tumors, testicular germ cell tumors (TGCTs) have the highest incidence among young men (between 20 and 34 years of age), and their incidence has increased over the past few decades. TGCTs have their origin in a blocked maturation of primordial germ cells (PGCs) (1-3), and more evidence has reinforced the idea that an alteration of epigenetic status is able to initiate human malignant germ cell tumors and to do so in the place of somatic mutations. This clarifies the role of both genetic susceptibility and environmental factors, known as the 'geno-environment', in TGCTs (4-9). About $90 \%$ of TGCTs are successfully treated with cisplatin-based chemotherapy. However, this form of therapy can lead to secondary cancers and cardiovascular disease. TGCTs are classified into two principal groups: germ cell neoplasias in situ (GCNIS) that are seminomas or nonseminomas (NSE), and spermatocytic tumors that are not GCNIS. NSE tumors encompass embryonal carcinoma, choriocarcinoma, yolk sac tumors (YSTs), and teratoma. TGCTs may develop from a non-invasive type of tumor called carcinoma in situ (CIS): microscopy reveals abnormal cells even though they are still confined inside the membrane of the seminiferous tubules (10-14).

MicroRNAs (miRNAs) are short non-coding RNA fragments that, by binding to the $3^{\prime}$ UTR, are able to negatively regulate gene transcripts (15). Thus, recent studies have underscored the fact that miRNA deregulation is a feature of carcinogenesis, including
TGCT development and progression (16-19). Although different miRNA signatures are associated with histological subtypes of TGCTs, various miRNAs have been found to play a key role in TGCTs. Voorhoeve et al. reported that two miRNAs (miR-372 and miR-373) can escape the cell cycle arrest induced by p53 (20). Indeed, these two miRNAs were not expressed or only slightly expressed in TGCT-derived cell lines where p53 was mutated or downregulated, indicating that miR-372 and miR-373 induce TGCT growth to elude the p53 checkpoint of the cell cycle. In this context, several data suggest that miR-372 and miR-373 may act as oncogenes in TGCTs through the inhibition of LATS2, a tumor suppressor gene (20). Dieckmann et al. confirmed that serum levels of microRNA (miR)-371a$3 p$ (a so-called M371 test) are better than the standard markers of GCT with the same level of sensitivity and a specificity of around $90 \%(21)$.

Moreover, Ozata et al. found that PEG3 mRNA can be strongly suppressed by the action of miR-514a$3 p$, inducing apoptosis. In particular, levels of PEG3 expression are elevated in TGCTs where the expression of miR-514a-3p is lacking (22).

Recent studies have reported that the deregulation of miRNA expression in cancer cells can modify the tumor microenvironment, inducing cancer progression. However, this mechanism has yet to be elucidated in TGCTs. Recent research has found that epigenetic modifications downregulate miR-125b in 
TGCT samples. Indeed, xenograft models of TGCTs indicated that miR-125b plays a key role in tumorstroma crosstalk, underscoring its tumor suppressor role and the possibility of using miR-125b as an miRNA therapeutic (23).

Intriguingly, both Let-7a and miR-26a were found to be downregulated in several human cancer types, acting as tumor suppressor miRNAs $(24,25)$. Moreover, these miRNAs inhibited cell proliferation and invasiveness of malignant melanoma derived-cell lines, suggesting that miR-26a and Let-7a may represent novel therapies for melanoma (26). Indeed, Let-7 is able to repress several oncogenes such as MYCN, AURKB, CCNF, RRM2, MKI67, and C12orf5 in TGCTs (27). A previous study determined that mitotic cells (spermatogonia and primary spermatocytes) express HMGA1, while HMGA2 is highly expressed in meiotic and postmeiotic cells (secondary spermatocytes and spermatids) $(28,29)$. In addition, other studies have demonstrated that the expression of HMGA1 and HMGA2 plays a key role in TGCT tumorigenesis and that the two can serve as a helpful diagnostic tool when the histological differential diagnosis is in question (30-36). In particular, HMGA1 protein is overexpressed in human seminomas.

Recently, De Martino and colleagues found that Let7a and miR-26a are downregulated in human seminoma, with levels negatively correlating with $H M G A 1$. In addition, they found that $H M G A 1$ is a target of Let-7a and miR-26a in seminomas and that Let-7a and miR-26a are able to inhibit seminoma cell growth and motility. Intriguingly, since miRNAs may act on several target transcripts that share the same microRNA responsive element (MRE) inhibitory action, a topic of great interest would be to study the transcriptomic effects of Let-7a and miR-26a overexpression in seminoma-derived cell lines using RNA-seq analysis in order to obtain a broader portrait of overall changes in levels of gene expression (37).

The study of the deregulated molecular pathways in TGCTs has now led to the development of successful clinical approaches. Indeed, most patients with TGCTs respond well to cisplatin-based chemotherapy. However, several patients have developed chemoresistance to firstline treatments for TGCTs. Therefore, new therapies based on novel strategies could increase the potential to treat cisplatin-resistant patients and limit adverse drug reactions. Interestingly, the ability of Let-7a and miR26a to prevent seminoma cell growth could lead to new insights in therapeutic perspectives. In fact, modern forms of therapy may originate from the restoration of normal Let-7a and miR-26a levels in seminomas via the administration of synthetic miRNA oligonucleotides.

\section{References}

1. Chieffi P. Molecular targets for the treatment of testicular germ cell tumors. Mini Rev Med Chem. 2007; 7:755-759.
2. Lobo J, Gillis AJM, Jerónimo C, Henrique R, Looijenga LHJ. Human germ cell tumors are developmental cancers: Impact of epigenetics on pathobiology and clinic. Int $\mathbf{J}$ Mol Sci. 2019; 20: 258

3. Franco R. Boscia F, Gigantino V, Marra L, Esposito F, Ferrara D, Pariante P, Botti G, Caraglia M, Minucci $\mathrm{S}$, Chieffi P. GPR30 is overexpressed in post-puberal testicular germ cell tumors. Cancer Biol Ther. 2011; 11: 609-613.

4. Chieffi P, Chieffi S, Franco R, Sinisi AA. Recent advances in the biology of germ cell tumors: Implications for the diagnosis and treatment. J Endocrinol Invest. 2012; 35:1015-1020.

5. Chieffi P, Chieffi S. Molecular biomarkers as potential targets for therapeutic strategies in human testicular germ cell tumours: an overview. J Cell Physiol. 2013; 22:16411646.

6. Chieffi P, Chieffi S. An up-date on newly discovered immunohistochemical biomarkers for the diagnosis of human testicular germ cell tumors. Histol Histopathol. 2014; 29:999-1006.

7. Chieffi P. An overview on predictive biomarkers of testicular germ cell tumors. J Cell Physiol. 2017; 232:276280.

8. Boscia F, Passaro C, Gigantino V, Perdonà S, Franco R, Portella G, Chieffi S, Chieffi P. High levels of GPR30 protein in human testicular carcinoma in situ and seminomas correlate with low levels of estrogen receptorbeta and indicate a switch in estrogen responsiveness. J Cell Physiol. 2015; 230:1290-1297.

9. Chieffi P, De Martino M, Esposito F. Further insights into testicular germ cell tumor oncogenesis: Potential therapeutic targets. Expert Rev Anticancer Ther. 2020; 20:189-195.

10. Vicini E, Loiarro M, Di Agostino S, Corallini S, Capolunghi F, Carsetti R, Chieffi P, Geremia R, Stefanini M, Sette C. 17- $\beta$-estradiol elicits genomic and nongenomic responses in mouse male germ cells. J Cell Physiol. 2006; 206:238-245.

11. Pero R, Lembo F, Chieffi P, Del Pozzo G, Fedele M, Fusco A, Bruni CB, Chiariotti L. Translational regulation of a novel testis-specific RNF4 transcript. Mol Reprod Dev. 2003; 66:1-7.

12. Picascia A, Stanzione R, Chieffi P, Kisslinger A, Dikic I, Tramontano D. Proline-rich tyrosine kinase 2 regulates proliferation and differentiation of prostate cells. Mol Cell Endocrinol. 2002; 186:81-87.

13. Sinisi AA, Chieffi P, Pasquali D, Kisslinger A, Staibano S, Bellastella A, Tramontano D. EPN: a novel epithelial cell line derived from human prostate tissue. In Vitro Cell Dev Biol Anim. 2002; 38:165-172.

14. Marra L, Cantile $\mathrm{M}$, Scognamiglio $\mathrm{G}$, Perdonà $\mathrm{S}, \mathrm{La}$ Mantia E, Cerrone M, Gigantino V, Cillo C, Caraglia M, Pignata S, Facchini G, Botti G, Chieffi S, Chieffi P, Franco R. Deregulation of HOX B13 expression in urinary bladder cancer progression. Curr Med Chem. 2013; 20:833-839.

15. Forzati F, De Martino M, Esposito F, Sepe R, Pellecchia S, Malapelle U, Pellino G, Arra C, Fusco A. miR-155 is positively regulated by $\mathrm{CBX} 7$ in mouse embryonic fibroblasts and colon carcinomas, and targets the KRAS oncogene. BMC Cancer. 2017; 17:170.

16. Wang L, Xu C. Role of microRNAs in mammalian spermatogenesis and testicular germ cell tumours. Reproduction. 2015; 149:R127- R137. 
17. Lu J, Getz G, Miska EA, Alvarez-Saavedra E, Lamb J, Peck D, Sweet-Cordero A, Ebert BL, Mak RH, Ferrando AA, Downing JR, Jacks T, Horvitz HR, Golub TR. MicroRNA expression profiles classify human cancers. Nature. 2005; 435:834-838.

18. Calin GA, Ferracin M, Cimmino A, Di Leva G, Shimizu M, Wojcik SE, Iorio MV, Visone R, Sever NI, Fabbri M, Iuliano R, Palumbo T, Pichiorri F, Roldo C, Garzon R, Sevignani C, Rassenti L, Alder H, Volinia S, Liu CG, Kipps TJ, Negrini M, Croce CM. A MicroRNA signature associated with prognosis and progression in chronic lymphocytic leukemia. N Engl J Med. 2005; 353:17931801.

19. Rounge TB, Furu K, Skotheim RI, Haugen TB, Grotmol T, Enerly E. Profiling of the small RNA populations in human testicular germ cell tumours shows global loss of piRNAs. Mol Cancer. 2015; 14:153.

20. Voorhoeve PM. le Sage C, Schrier M, Gillis AJ, Stoop H, Nagel R, Liu YP, van Duijse J, Drost J, Griekspoor A, Zlotorynski E, Yabuta N, De Vita G, Nojima H, Looijenga LH, Agami R. A genetic screen implicates miRNA-372 and miRNA-373 as oncogenes in testicular germ cell tumors. Cell. 2006; 124:1169-1181.

21. Dieckmann KP, Radtke A, Geczi L, Matthies C, Anheuser $\mathrm{P}$, Eckardt U, Sommer J, Zengerling F, Trenti E, Pichler R, Belz H, Zastrow S, Winter A, Melchior S, Hammel J, Kranz J, Bolten M, Krege S, Haben B, Loidl W, Ruf CG, Heinzelbecker J, Heidenreich A, Cremers JF, Oing C, Hermanns T, Fankhauser CD, Gillessen S, Reichegger H, Cathomas R, Pichler M, Hentrich M, Eredics K, Lorch A, Wülfing C, Peine S, Wosniok W, Bokemeyer C, Belge G. Serum levels of MicroRNA-371a-3p (M371 test) as a new biomarker of testicular germ cell tumours: Results of a prospective multicentric study. J Clin Oncol. 2019; 37:1412-1423

22. Ozata DM, Li X, Lee L, Liu J, Warsito D, Hajeri P, Hultman I, Fotouhi O, Marklund S, Ahrlund-Richter L, Juhlin CC, Larsson C, Lui WO. Loss of miR-514a-3p regulation of PEG3 activates the NF-kappa $\mathrm{B}$ pathway in human testicular germ cell tumors. Cell Death Dis. 2017; 8:e2759.

23. Batool A, Wang YQ, Hao XX, Chen SR, Liu YX. A miR125b/CSF1-CX3CL1/tumor-associated macrophage recruitment axis controls testicular germ cell tumor growth. Cell Death Dis. 2018; 9:962.

24. Yang X, Zhang XF, Lu X, Jia HL, Liang L, Dong QZ, Ye $\mathrm{QH}$, Qin LX. MicroRNA-26a suppresses angiogenesis in human hepatocellular carcinoma by targeting hepatocyte growth factor-cMet pathway. Hepatology. 2014; 59: 18741885.

25. Mi Y, Liu F, Liang X, Liu S, Huang X, Sang M, Geng C. Tumor suppressor let-7a inhibits breast cancer cell proliferation, migration and invasion by targeting MAGE-A1. Neoplasma. 2019; 66:54-62.

26. Qian H, Yang C, Yang Y. MicroRNA-26a inhibits the growth and invasiveness of malignant melanoma and directly targets on MITF gene. Cell Death Discov. 2017;
3:17028.

27. Murray MJ, Saini HK, Siegler CA, Hanning JE, Barker EM, van Dongen S, Ward DM, Raby KL, Groves IJ Scarpini CG, Pett MR, Thornton CM, Enright AJ, Nicholson JC, Coleman N CCLG. LIN28 Expression in malignant germ cell tumors downregulates let-7 and increases oncogene levels. Cancer Res. 2013; 73:48724884.

28. Chieffi P, Battista S, Barchi M, Di Agostino S, Pierantoni G, Fedele M, Chiariotti L, Tramontano D, Fusco A. HMGA 1 and HMGA2 protein expression in mouse spermatogenesis. Oncogene. 2002; 21:3644-3650.

29. Di Agostino S, Fedele M, Chieffi P, Fusco A, Rossi P, Geremia R, Sette C. Phosphorylation of high mobility group protein $\mathrm{A} 2$ by Nek2 kinase during the first meiotic division in mouse spermatocytes. Mol Biol Cell. 2004; 15:1224-1232.

30. Franco R, Esposito F, Fedele M, Liguori G, Pierantoni G, Botti G, Tramontano D, Fusco A, Chieffi P. Detection of high mobility group proteins $\mathrm{A} 1$ and $\mathrm{A} 2$ represents a valid diagnostic marker in post-puberal testicular germ cell tumours. J Pathol. 2008; 214:58-64.

31. Esposito F, Boscia F, Gigantino V, Tornincasa M, Fusco A, Franco R, Chieffi P. The high mobility group A1oestrogen receptor $\beta$ nuclear interaction is impaired in human testicular seminomas. J Cell Physiol. 2012; 227:3749-3755.

32. Chieffi P, De Martino M, Esposito F. New anti-cancer strategies in testicular germ cell tumors. Recent Pat Anticancer Drug Discov. 2019; 14:53-59.

33. Chieffi P. Recent advances in molecular and cell biology of testicular germ-cell tumors. Int Rev Cell Mol Biol. 2014; 312:79-100.

34. De Martino M, Fusco A, Esposito F. HMGA and cancer: A review on patent literatures. Recent Pat Anticancer Drug Discov. 2019; 14:258-267.

35. Chieffi P. An up-date on epigenetic and molecular markers in testicular germ cell tumors. Intractable Rare Dis Res. 2017; 6:319-321.

36. Chieffi P. An up-date on novel molecular targets in testicular germ cell tumors subtypes. Intractable Rare Dis Res. 2019; 8:161-164.

37. De Martino M, Esposito F, Pellecchia S, Cardoso Penha RC, Botti G, Fusco A, Chieffi P. HMGA1-Regulating microRNAs Let-7a and miR-26a are downregulated in human seminomas. Int J Mol Sci. 2020; 21:3014. doi: 10.3390/ijms21083014.

Received April 27, 2020; Accepted May 30, 2020.

*Address correspondence to:

Paolo Chieffi, Dipartimento di Psicologia, Università della Campania "Luigi Vanvitelli", Caserta, 3181100 Caserta, Italy. E-mail: paolo.chieffi@unicampania.it

Released online in J-STAGE as advance publication June 4, 2020 . 